\title{
Alteração hidrotermal e mineralização aurífera do Prospecto São Francisco, Província Aurífera de Alta Floresta (MT), Cráton Amazônico
}

\author{
Halina T. Kondrasovas (IC)

\section{Resumo} \\ Localizado na Província Aurífera de Alta Floresta, o Prospecto São Francisco consiste em um depósito cuja \\ mineralização aurífera encontra-se hospedada em rochas graníticas alteradas hidrotermalmente. A \\ caracterização dessas alterações constitui uma importante ferramenta para o estudo dessas mineralizações \\ e seus litotipos associados, bem como sua correlação com outros depósitos auríferos.
}

Palavras Chave: alteração hidrotermal, mineralização aurífera, PAAF.

\section{Introdução}

Na Província Aurífera de Alta Floresta (PAAF), localizada na porção centro-sul do Cráton Amazônico, são encontrados centenas de depósitos auríferos, especialmente em seu setor leste. Nesse contexto, está o Prospecto São Francisco, com mineralizações auríferas hospedadas em rochas graníticas associadas a zonas com alterações hidrotermais.

A compreensão dos mecanismos de alteração hidrotermal pode ser uma ferramenta útil no estudo de diversas mineralizações auríferas, como em depósitos do tipo ouro orogênico, associados a sistemas intrusivos (intrusionrelated gold deposits- IRGS), do tipo pórfiro, epitermal e Carlin, entre outros. O projeto buscou caracterizar as alterações hidrotermais que ocorrem no Prospecto São Francisco. Para isso foram realizadas descrições de três testemunhos de sondagem, bem como análise petrográfica dos principais litotipos associados

\section{Resultados e Discussão}

Notou-se que a mineralização encontra-se hospedada numa rocha granítica acinzentada, classificada como biotita-granodiorito a tonalito. Nas zonas proximais aos veios de quartzo há ocorrência de alteração potássica com feldspato potássico, que confere a rocha uma coloração rosada, e vênulas de calcita+ quartzo \pm epídoto \pm pirita.

Uma segunda forma de alteração que afeta os litotipos é a fílica, ou sericítica, que ao afetar a rocha granítica resulta numa rocha de granulação fina, de coloração esverdeada, rica em quartzo, clorita e sericita.

Além disso, vênulas de composições diversas (calcita, epídoto e clorita) foram encontradas em fraturas e nos interstícios minerais, evidenciando a existência de eventos tardios. Observa-se que a mineralização ocorre principalmente em veios de quartzo \pm carbonato sulfetados, caracterizada por pirita \pm calcopirita e fortemente associados à alteração fílica.

\section{Conclusões}

A partir da análise dos testemunhos de sondagem, foi possível compreender o contexto no qual a mineralização do prospecto se insere. Observou-se que a hospedeira dessa mineralização é um Biotita-granodiorito a tonalito, que apresenta-se alterado por duas principais alterações hidrotermais: (i) alteração potássica com feldspato potássico; e (ii) alteração sericítica, com clorita e sericita, que mostra uma forte correlação com a ocorrência de mineralizações.

Além disso, os dados de campo permitiram concluir que o depósito São Francisco apresenta características semelhantes, como hospedeira e tipos de alteração hidrotermal, a outros depósitos do setor leste da PAAF hospedados em rochas graníticas (Assis et al., 2014) ${ }^{\uparrow}$.

\section{Agradecimentos}

Gostaria de agradecer a disponibilidade da PA GOLD em fornecer o conteúdo necessário para este projeto e a meu orientador, o Prof. Dr. Roberto Perez Xavier, por toda ajuda e compreensão.

\footnotetext{
${ }^{1}$ Assis, R.R., Xavier, R.P., Paes de Barros, A.J., Miguel Júnior, E., Teixeira, R.V., Rodrigues, R.M., Santos, T.J.S., Ramos, G.S., Stabile Júnior, A., Trevisan, V.G., Miranda, G.M.T. Metalogênse dos depósitos auríferos associados a sistemas graníticos do setor leste da Província de Alta Floresta (MT), Cráton Amazônico. In: Jost, H., Kuiyumjian, R. e Silva, M.G., Metalogenia do Precambriano Brasileiro. CPRM, Capítulo de livro. No prelo.
} 